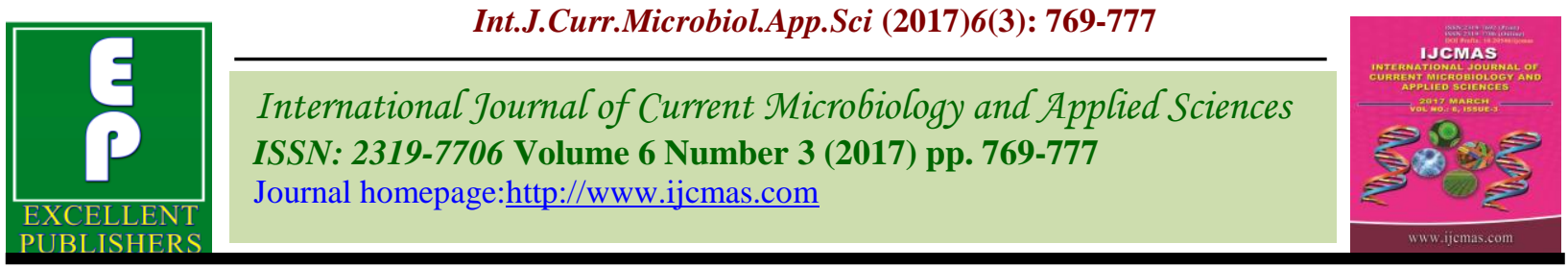

Original Research Article

https://doi.org/10.20546/ijcmas.2017.603.089

\title{
Performance of Green Super Rice 5 Genotype under Different Water Management Schemes
}

\author{
Michael M. Uy ${ }^{1}$ and Samuel R. Simon ${ }^{2} *$ \\ ${ }^{1}$ Cagayan State University, Piat Campus, Piat, 3527 Cagayan, Philippines \\ ${ }^{2}$ Isabela State University, Cabagan Campus, Cabagan, 3328 Isabela Philippines \\ *Corresponding author
}

\section{Keywords}

Green super rice, alternate wetting and drying, water management scheme, continuous flooding, field capacity.

Article Info

Accepted:

15 February 2017

Available Online:

10 March 2017

\section{A B S T R A C T}

The study was conducted to determine the effect of different water management schemes on the growth and yield of green super rice 5 (GSR 5) genotype. The experiment was laid out using Randomized Complete Block Design (RCBD) to test the following treatments: Treatment 1 - Alternate Wetting and Drying (AWD); Treatment 2 - Continuous Flooding (CF); and Treatment 3 - Field Capacity (FC).The GSR 5 subjected to different water management schemes revealed comparable data in almost all agronomic and yield traits as it exhibited no significant differences in terms of number of days to $50 \%$ flowering, number of days to maturity, height at maturity $(\mathrm{cm})$, number of productive tillers, panicle length $(\mathrm{cm})$, filled and unfilled grains, biomass yield $(\mathrm{g})$, weight of 1000 grains $(\mathrm{g})$ and grain yield per hectare. However, in terms of root length, Treatment 1 significantly obtained the longest. Even with insignificant variations among the three water management schemes, alternate wetting and drying revealed better results compared with the other treatments in most of the parameters considered. Moreover, the reduction in the frequency of water application in AWD scheme resulted to a significant decrease in the cost of irrigation without significant reduction in the yield. Hence, the application of AWD scheme is recommended for GSR 5 production.

\section{Introduction}

Rice is a semi-aquatic plant species that originated in tropical swamps. Conventionally, rice production typically consumes 2-3 times water as other cereals do. Thus, water deficiency or drought has been one among the major limiting factors in rainfed rice fields. With drought at the early stages of growth, germination will be delayed. Drought at the reproductive stage also slows growth and development resulting to low yield (Ali et al., 2013).

Green super rice (GSR) is a term coined to describe the characteristics of the variety made through tedious cross-breeding of hundreds of varieties and lines of rice. "Green" does not only signify its color but also because it is environmentally friendly as it will grow as much or more grain with lesser inputs. Likewise, it is not a product of genetic engineering (Watson, 2014). Parental lines used to have been screened through molecular marker-based genetic analyses by which specific locus for specific characteristics were determined. "Super", on the other hand, means the rice is designed to better resist droughts, floods, salty water, insects and diseases. 
Water is one of the limiting factors in rice production. With the onset of climate change and due to the effect of dry spell (El Niňo), rice production in the country has declined. Thus, supply of rice to meet the needs of the increasing population is a problem. Despite efforts of research institutions to address the problem of producing drought tolerant rice varieties, seemingly the scarce supply of rice still beset the countryside.

The increasing world's water scarcity problems brought about by the increasing demands of fresh water for urban or industrial uses and agricultural production, specifically irrigated lowland rice production. These situations is aggravated by the decreasing watershed areas due to continuous denudation of forest by illegal loggers and slash and burn farmers that resulted to soil erosion at higher elevation and caused siltation and drying out of most bodies of surface water. The above situation threatens not only the capacity of the agricultural sector to produce and supply the food demands of the escalating human population, but also the sustainability of the irrigated rice production system.

According to Bouman and Tuong (2001), rice production is facing increasing competition with rapid urban and industrial development in terms of freshwater resource. The need for "more rice with less water" is crucial for food security and irrigation plays a greater role in meeting future food needs than it has in the past (Tuong et al., 2004).

This research endeavor will therefore provide indispensable valuable benchmark information to farmers. Meanwhile, researchers continue stacking more traits into new varieties to help farmers produce more with less resources and impacts in order to feed a growing world and one of it is the green super rice.
The study aimed to evaluate the growth and yield performance of green super rice 5 under different water management schemes and perform a simple cost and return analysis of the different treatments.

\section{Materials and Methods}

The GSR 5 used in the study was secured at Southern Cagayan Research Center at Minanga Norte, Iguig, Cagayan, Philippines.

An area of 16 meters x 13 meters was used for the study in which the area was thoroughly prepared and laid out using the Randomized Complete Block Design (RCBD) with three replications each. Paddy levees were covered with plastic materials to avoid seepage. The following treatments were applied: Treatment 1 - Alternate Wetting and Drying (AWD); Treatment 2 - Continuous Flooding (CF); and Treatment 3 - Field Capacity (FC).

\section{Water management schemes}

$\mathrm{T}_{1}$ - Alternate Wetting and Drying - field water tubes known as "Pani Pipe" were installed using $15 \mathrm{~cm}$ diameter and $30-\mathrm{cm}$ long plastic pipe, so that the water level is visible, and easy to remove the soil inside (Figure 1). The tube was perforated with many holes on all sides, so that water can flow readily in and out of the tube. The perforated tube was buried into the soil until $15 \mathrm{~cm}$ protrudes above the soil surface. The tube was placed in the corresponding treatment in a readily accessible part of the field close to a bund, so it is easy to monitor the ponded water depth. When the water level has dropped to about $15 \mathrm{~cm}$ below the surface of the soil, irrigation was applied to re-flood the field to a depth of about $5 \mathrm{~cm}$ at the surface. 
$\mathrm{T}_{2}$ - Continuous Flooding - the depth of water was maintained following the International Rice Research Institute (IRRI) technology as follows: (a) $2 \mathrm{~cm}$ depth after transplanting up to tillering stage, (b) $5 \mathrm{~cm}$ depth during booting stage, and (c) $3 \mathrm{~cm}$ depth during milking stage to maturity.

$\mathrm{T}_{3}$ - Field Capacity- irrigation was done after $50 \%$ of the field capacity was depleted. Digital moisture meter was used to monitor the field capacity.

\section{Results and Discussion}

\section{Number of days at $50 \%$ flowering}

The number of days at $50 \%$ flowering of green super rice subjected to different water management schemes is presented in figure 2 . Results show that the crop produced flowers almost at the same time regardless of the water management schemes with means ranging from 81 - 82 days after sowing (DAS) with no significant differences noted. This means that the three water management did not affect the crop in terms of this parameter.

\section{Number of days to maturity}

The mean number of days to maturity of green super rice 5 is reflected in figure 3 . Data shows the same trend of response with that number of days to flowering where $T_{1}$ was the earliest to produce flower with a mean of 113 days followed $T_{2}$ and $T_{3}$ with a mean of 115 and 116 days, respectively. No significant difference among the three water management was noted.

\section{Height at maturity $(\mathrm{cm})$}

Figure 4 presents the mean height $(\mathrm{cm})$ at maturity of GSR 5 genotype as affected by different water management schemes. Crops under $\mathrm{T}_{1}$ have registered the tallest with a mean of $102 \mathrm{~cm}$, closely followed by $\mathrm{T}_{3}$ and $\mathrm{T}_{2}$ with a mean of 101 and $102 \mathrm{~cm}$, respectively. Despite numerical variations, analysis of variance revealed no significant difference among the treatment in terms of height of the rice crop.

\section{Number of productive tillers per hill}

As shown in figure 5, $\mathrm{T}_{2}$ (Continuous Flooding) had the most number of productive tillers with a mean of 14 and the least was obtained in T3 (Field Capacity) with a mean of 13 .

It can be observed from the figure that despite the numerical disparities, the production of tillers did not vary significantly regardless of the water management schemes. This implies that green super rice 5manifested the similar trend of response on the different water management schemes.

\section{Root length (cm)}

Figure 6 showed the longest roots which was produced by $\mathrm{T}_{1}$ (Alternate Wetting and Drying) with a mean of $32.1 \mathrm{~cm}$ followed by $\mathrm{T}_{3}$ (Field Capacity) and $\mathrm{T}_{2}$ (Continuous Flooding) with a mean of $30.1 \mathrm{~cm}$ and 29.5 $\mathrm{cm}$, respectively. No significant difference among the different water management tested. This means that green super rice 5 responded differently when exposed to water management regimes. It was observed however that rice plants exposed to lesser water supply produced longer roots. This implies that roots, being an integral part of the rice plant, have various adaptive mechanisms in response to soil water stress conditions in the acquisition of nutrients and water (Yamauchi et al., 1996).

The graphical data on the length of panicle (cm) of green super rice 5 subjected to water 
management is illustrated in figure 7 . Figure revealed that the three water management schemes employed did not give any significant effect on the length of panicles of the different green super rice genotypes which recorded a panicle length that ranges from $25.5-26.6 \mathrm{~cm}$.

\section{Number of filled grains per panicle}

Figure 8 shows that $T_{1}$ had the most number of filled grains with a mean of 153 , closely followed by $T_{3}$ with a mean of 149 . The least number of filled grains per panicle was obtained in $\mathrm{T}_{2}$ with a mean of 113. Statistical analysis, however, showed no significant difference among treatments tested.

\section{Number of unfilled grains per panicle}

Figure 9 presents the number of unfilled grains per panicle of green super rice 5 subjected to different water management schemes. Results revealed that the highest number of unfilled grains was registered by $\mathrm{T}_{3}$ with a mean of 27 . The least number of unfilled grains per panicle was obtained in $T_{1}$ and $\mathrm{T}_{2}$ with a mean of 24 . No significant difference was noted among the three water management tested as revealed by the analysis of variance.

\section{Biomass yield}

As presented in figure $10, \mathrm{~T}_{1}$ (AWD) obtained the heaviest biomass yield with a mean of 1,193 grams followed by $\mathrm{T}_{3}$ (Field Capacity) and $\mathrm{T}_{2}$ (Continuous Flooding) with a mean of 1, 170 and 1,088.33 grams, respectively. Analysis of variance shows no significant difference effect among the water management schemes on this parameter.

\section{Weight of 1000 grains}

The average weight of 1000 grains (grams) of green super rice 5 subjected to water management schemes are shown in figure 11. Data showed very slight differences among seeds obtained from plots regardless of water management, with mean weights ranging from $25.4-25.9$ grams.

\section{Computed yield}

Figure 12 presents the computed yield in tons/ha of the GSR 5 subjected to different management schemes. As shown in the figure, the test crop under $\mathrm{T}_{2}$ obtained the highest yield with 7.11 tons/ha closely followed by $T_{1}$ and $T_{3}$ with a yield of 7.01 and 6.8 (tons/ha). Analysis of variance shows no significant difference among the three treatments tested. The disparities in yield is probably due to the genotype differences as observed from the different yield component parameters e.g. panicle length, number of spikelet per panicle and tiller count. The alternate irrigation application and its suspension ensured deeper growth of the root system and access to water and nutrients uptake ensuring optimum growth and high grain yield (Zhi, Undated).

\section{Cost and return analysis}

As reflected in table 1, the highest production cost is $\mathrm{T}_{2}$ (Continuous Flooding) with P38, 280.00, closely followed by $\mathrm{T}_{3}$ (Field Capacity) and $\mathrm{T}_{1}$ (Alternate Wetting and Drying) with P36, 469.00 and P35, 613.00, respectively.

The highest gross income of P108, 160.00 was obtained in $\mathrm{T}_{2}$ (Continuous Flooding), P104, 320.00 in $\mathrm{T}_{1}$ (Alternate Wetting and Drying) and P101, 920.00 in $\mathrm{T}_{3}$ (Field Capacity). This implies that the higher the field activity (irrigation), the higher is the cost of production. In terms of the net income, $\mathrm{T}_{2}$ has $\mathrm{P} 69,880.00, \mathrm{~T}_{1}$ has $\mathrm{P} 68,707.00$ and $\mathrm{T}_{3}$ has P65,451.00. 
Table.1 Cost and return analysis of GSR 5 under different water management schemes

\begin{tabular}{|l|r|r|r|}
\hline \multirow{2}{*}{ Description } & \multicolumn{3}{|c|}{ Treatment } \\
\cline { 2 - 4 } & \multicolumn{1}{|c|}{ I } & \multicolumn{1}{c|}{ III } \\
\hline $\begin{array}{l}\text { Total Cost of } \\
\text { Production } \\
\text { (Php) }\end{array}$ & $35,613.00$ & $38,280.00$ & $36,469.00$ \\
\hline $\begin{array}{l}\text { Gross Sales } \\
\text { (Php) }\end{array}$ & $104,320.00$ & $108,160.00$ & $101,920.00$ \\
\hline $\begin{array}{l}\text { Net Income } \\
\text { (Php) }\end{array}$ & $68,707.00$ & $69,880.00$ & $65,451.00$ \\
\hline $\begin{array}{l}\text { Return on } \\
\text { Investment } \\
\text { (Php) }\end{array}$ & 192.93 & 182.55 & 179.47 \\
\hline $\begin{array}{l}\text { Net Return per } \\
\text { Peso Invested }\end{array}$ & 1.93 & 1.83 & 1.79 \\
\hline
\end{tabular}

Fig.1 Pani pipe tube installed in the field
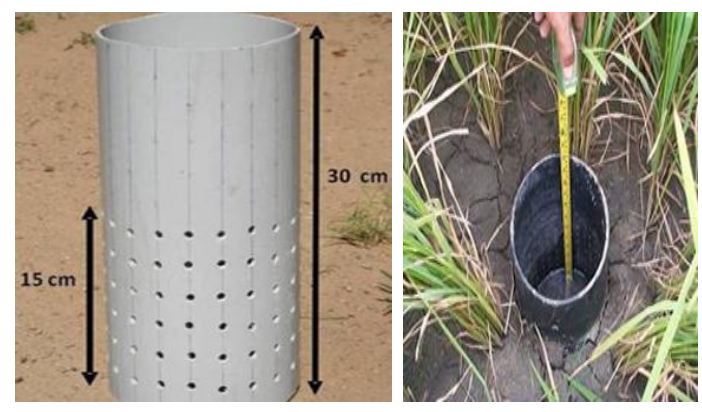

Fig.2 Number of days at 50\% flowering of GSR 5subjected to different water Management schemes

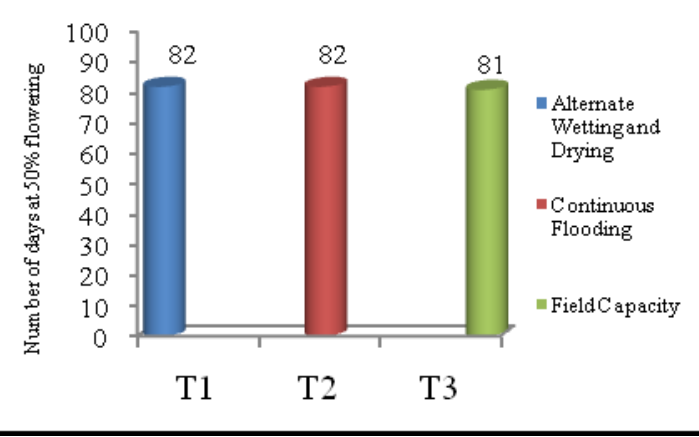


Fig.3 Number of days to maturity of GSR 5subjected to different water management schemes

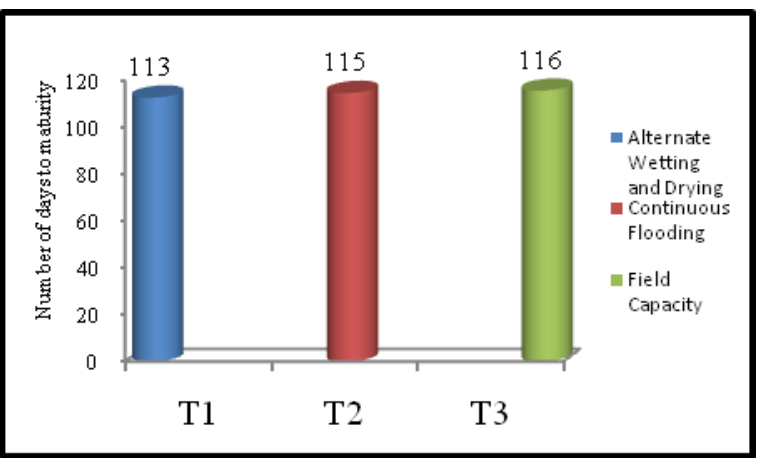

Fig.4 Height at maturity $(\mathrm{cm})$ of GSR 5 subjected to different water management schemes

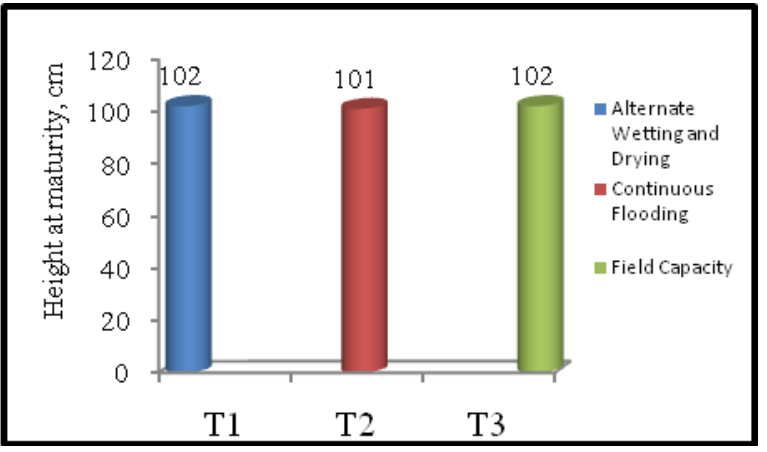

Fig.5 Number of productive tillers per hill of GSR5 subjected to different water management schemes

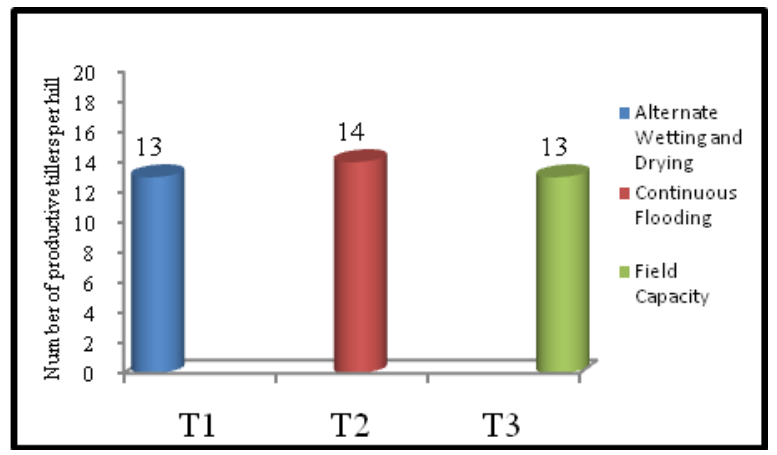

Fig.6 Root length (cm) of GSR 5 subjected to different water management schemes

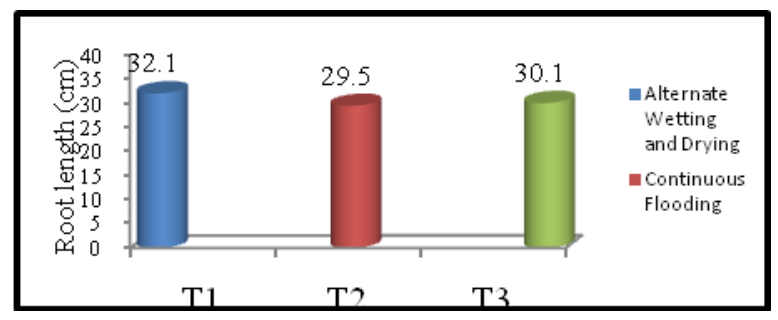


Fig.7 Length of panicle $(\mathrm{cm})$ of GSR 5 subjected to different water management schemes

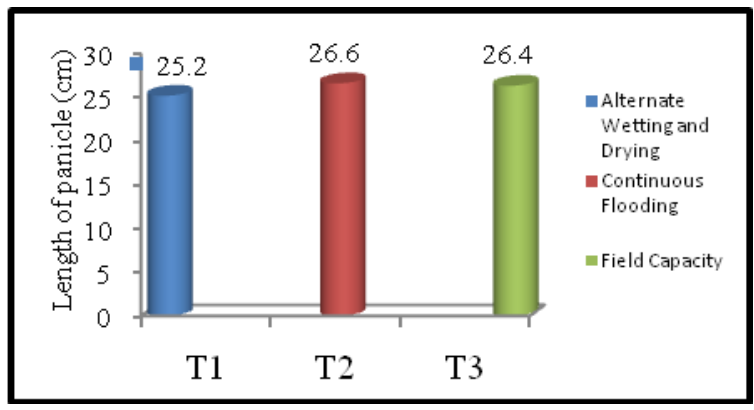

Fig.8 Number of filled grains per panicle of GSR 5 subjected to different water management schemes

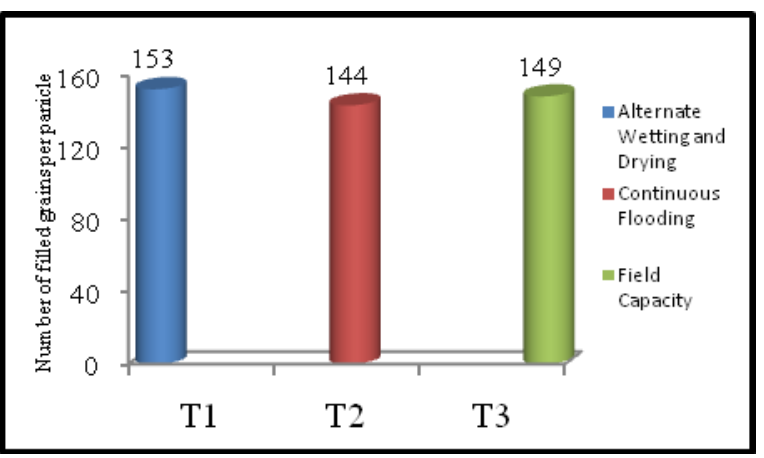

Fig.9 Number of unfilled grains per panicle of GSR 5subjectedto different water management schemes

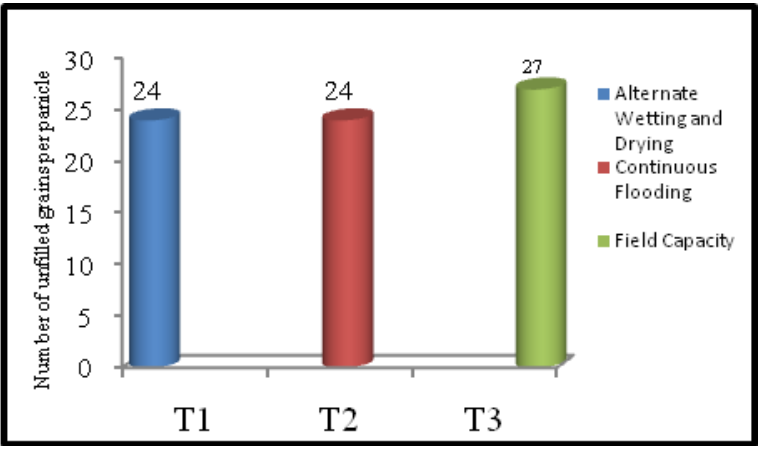

Fig.10 Biomass yield (grams) of GSR 5 subjected to different water management schemes

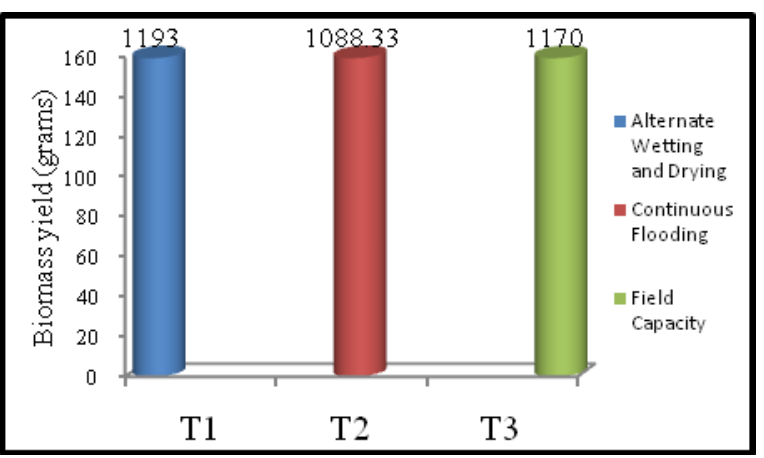


Fig.11 Weight of 1000 grain (grams)of GSR 5 subjected to different water management schemes

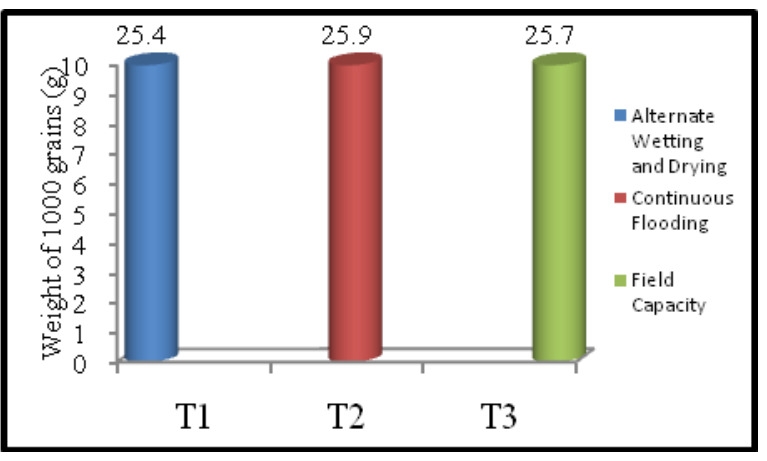

Fig.12 Computed yield (tons/ha) of GSR 5 subjected to different water management schemes

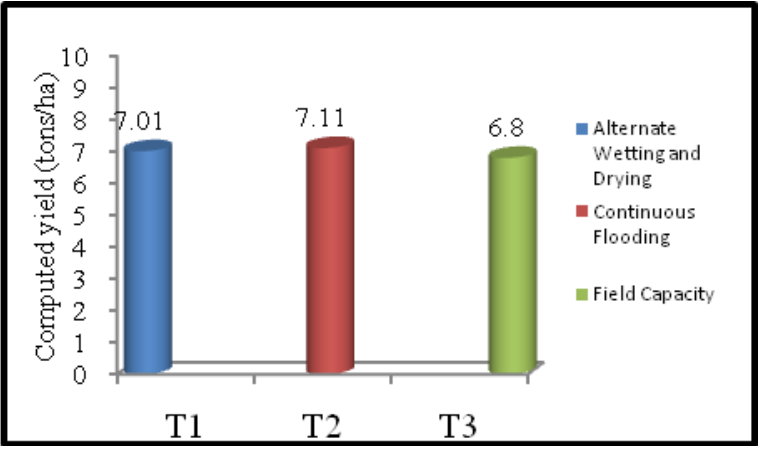

On the relative value, the net income per peso invested (NRPI) was 1.93 per peso for $T_{1}$ followed by $\mathrm{T}_{2}$ with 1.83 per peso and $\mathrm{T}_{3}$ with 1.79 per peso invested. The low net return per peso invested in $T_{3}$ is due to high cost of production particularly on labor.

In conclusion, based on the result of the study, the following conclusions were drawn:

1. The three water management schemes did not show significant effect on almost all the parameters measured, except for the root length which showed significant result. Rice plants exposed to lesser water supply produced longer roots.

2. The highest income was obtained from $T_{2}$ (Continuous Flooding) with P69, 880.00, closely followed by $\mathrm{T}_{1}$ (Alternate Wetting and Drying) and $\mathrm{T}_{3}$ (Field Capacity) with a corresponding income of P68, 707.00 and
P65, 451.00, respectively.

3. $\mathrm{T}_{2}$ (Continuous Flooding) obtained the highest cost of production and the least was $\mathrm{T}_{1}$ (Alternate Wetting and Drying).

4. $\mathrm{T}_{1}$ (Alternate Wetting and Drying) obtained the highest NRPI of 1.93 .

\section{Recommendation}

The application of alternate wetting and drying as a water management scheme is recommended as it reduces water input by as much as $15-30 \%$ without significant yield loss.

\section{Acknowledgement}

The authors wish to extend their profound gratitude to the Cagayan State University and Isabela State University for all the 
administrative support. Likewise, to all the people who in one way or the other tendered their helping hands for the completion of this study.

\section{References}

Adeyemi, R.A., Gana, A.S. and S.T. Yusuf. 2011. Biometrical character interrelationship and morphological variations in some upland rice(oryza sativa 1.) varieties. African J. Food, Agriculture, Nutrition and Development. Volume 11 No. 2, ISSN 16845374.

Bouman, B.A.M. and Tuong, T.P. 2001. "Field water management to save water and increase its productivity in irrigated lowland rice," Agri. Water Management, vol. 49, no. 1, pp. 11-30.

Singh, A., Singh, P.K., Singh, R., Pandit, A., Mahato, A.K., Gupta, D.K., Tyagi, K., Singh, A.K., Singh, N.K. and Sharma, T.R. 2010. SNP haplotypes of the
BADH1 gene and their association with aroma in rice (Oryza sativa L.). Mol. Breeding, DOI: 10.1007/s11032-0109425-1.

Tuong, T.P., Bouman, B.A.M., and Martian, M. 2004. More rice, "less waterintegrated approaches for increasing water productivity in irrigated ricebased systems in Asia," in Proceedings of the 4th International Crop Science Congress, Brisbane, Australia.

Yamauchi, Y., J.R.J. Pardales and Y. Kono, 1996. Root system structure and its relation to stress tolerance. In O. Ito, K. Katayama, C. Johansen, J. V. D. K. K. Rao, J. J. Adu-Gyamfi \& T. J. Rego (Eds.), Roots and Nitrogen in Cropping Systems of the Semi-Arid Tropics (pp. 211-234). Tsukuba, Japan: JIRCAS Publication.

Zhi, M., Undated. 2009. Water efficient irrigation and environmentally sustainable irrigated production in China.

\section{How to cite this article:}

Michael M. Uy and Samuel Simon, R. 2017. Performance of Green Super Rice 5 Genotype under Different Water Management Schemes. Int.J.Curr.Microbiol.App.Sci.6(3): 769-777. doi: https://doi.org/10.20546/ijcmas.2017.603.089 